\title{
The Selection of Neural Network Input Parameters Based on Association Rules
}

\author{
Lei Shi* \\ College of Engineering, Bohai University, Jinzhou 121000, China \\ ${ }^{*}$ Corresponding author
}

\begin{abstract}
Neural network has strong ability of nonlinear approximation and fitting, which was widely used in various prognosis prediction researches. Meanwhile, the selection of neural network input parameters was very important: the number of input layer nodes would increase as the number of input parameters and it required a large number of sample data to train the neural network, which was very easy to cause the dimension disaster. Otherwise, the sample data and the local extremums in the process of convergence would decrease as the number of input parameters, which could simplify the topology of the neural network prediction model greatly. In this paper, we used association rules based on data mining to select input parameters of the neural network prediction model of cervical spinal cord injury and reduced its dimensionality from 25 to 7 . Finally, the good performance is proved through the simulation results using MATLAB.
\end{abstract}

Keywords-neural network; association rules; parameter selection; dimension reduction

\section{INTRODUCTION}

As always, how to determine the neural network input variables reasonably and how to avoid dimension disaster caused by too much inputs have been explored by researchers. Usually, the solutions to this problem mainly includes cluster analysis, data mining method, principal component analysis, mechanism analysis, empirical method and trial-and-error method. So it needs to choose the methods based on comprehensive analysis according to their own characteristics. In this paper, we used association rules based on data mining to select input parameters of the neural network prediction model of cervical spinal cord injury and reduces its dimensionality. The association rules considers many factors of cervical spinal cord injury as well as avoid the complex structure of neural network topology and long training time caused by too much input variables. Finally, the simulation test has proved its superiority.

\section{SCREENING PROCESS}

This paper takes the prognosis of cervical spinal cord injury as object, and predicts the 1-year walking-rate using neural network. In previous studies, there were about 25 parameters in this prediction model in combination with related literature and clinical doctors diagnose. However, it's showed that not all parameters played a positive role on the prediction results. Therefore, it's very important to select effective parameters as input nodes of the neural network.

\section{A. Establishing a Knowledge Itemset D}

It should be noted that the knowledge itemset $\mathrm{D}$ need to be selected repeatedly in order to achieve satisfactory effect in basis on recording the results of the measurement and analysis during selecting the training parameters, and the concrete steps are:

1. Selecting the parameter and analyzing its performance.

2. Recording the result of selection and generating the data subset $\mathrm{T} 1$.

3. Comparing the previous results and adjusting the input parameters.

4. Recording the result of selection again and generating the data subset $\mathrm{T} 2$.

5. Repeating the above steps to $30-50$ records.

The knowledge itemset $\mathrm{D}$ could be established by the above steps, and it's noted that the number of records is connected with the number of input parameters. In this paper, it took 5-6 hours to get about 140 records, and the test results was shown in Table 1, among which, " 1 " indicated that the parameter is selected and " 0 " indicated that the parameter isn't selected. 
TABLE I. THE SELECTION OF INPUT PARAMETERS (PART OF PARAMETER)

\begin{tabular}{|c|c|c|c|c|c|c|c|c|}
\hline $\begin{array}{l}\text { parameter } \\
\text { No. }\end{array}$ & age & sex & $\begin{array}{l}\text { injury } \\
\text { cause }\end{array}$ & $\begin{array}{l}\text { injury } \\
\text { degree }\end{array}$ & $\begin{array}{c}\text { neurogenic } \\
\text { shock }\end{array}$ & $\begin{array}{c}\text { elapsed } \\
\text { time to } \\
\text { hospital }\end{array}$ & $\begin{array}{l}\text { hypona- } \\
\text { tremia }\end{array}$ & $\cdots$ \\
\hline 1 & 1 & 0 & 1 & 1 & 0 & 1 & 0 & $\ldots$ \\
\hline 2 & 0 & 1 & 1 & 1 & 0 & 0 & 1 & $\ldots$ \\
\hline 3 & 0 & 1 & 0 & 1 & 0 & 1 & 0 & $\ldots$ \\
\hline 4 & 1 & 0 & 1 & 1 & 0 & 0 & 0 & $\ldots$ \\
\hline 5 & 1 & 1 & 0 & 1 & 0 & 0 & 0 & $\ldots$ \\
\hline$\ldots \ldots$ & $\begin{array}{l}\ldots \ldots \\
\end{array}$ & $\ldots \ldots$ & ...... & ...... & $\ldots \ldots$ & $\ldots \ldots$ & ....... & $\ldots$ \\
\hline $\begin{array}{l}\text { No. } \\
\text { Narameter }\end{array}$ & $\begin{array}{c}\text { blood } \\
\text { pressure }\end{array}$ & $\begin{array}{l}\text { heart } \\
\text { rate }\end{array}$ & $\begin{array}{c}\text { injury } \\
\text { segment }\end{array}$ & $\begin{array}{c}\text { tracheo- } \\
\text { tomy }\end{array}$ & $\begin{array}{c}\text { central } \\
\text { hyperther- } \\
\text { mia } \\
\end{array}$ & $\begin{array}{c}\text { elapsed } \\
\text { time to } \\
\text { operation }\end{array}$ & $\begin{array}{l}\text { pulmonary } \\
\text { infection }\end{array}$ & $\cdots$ \\
\hline 1 & 1 & 0 & 1 & 0 & 0 & 0 & 0 & $\ldots$ \\
\hline 2 & 0 & 1 & 1 & 0 & 0 & 1 & 0 & $\ldots$ \\
\hline 3 & 1 & 0 & 1 & 0 & 1 & 0 & 0 & $\ldots$ \\
\hline 4 & 1 & 1 & 0 & 1 & 0 & 0 & 1 & $\ldots$ \\
\hline 5 & 1 & 0 & 1 & 0 & 0 & 1 & 0 & $\ldots$ \\
\hline ...... & $\ldots \ldots$ & $\ldots \ldots$ & $\ldots \ldots$ & ...... & $\ldots \ldots$ & $\ldots \ldots$ & ...... & $\ldots$ \\
\hline
\end{tabular}

In this paper, there were 25 parameters in this prediction model. when different number and combinations of input parameters have been selected to train the neural network, there would be different prediction accuracy of the prediction model, which was showed in Table 2.

TABLE II. THE PREDICTION ACCURACY OF THE PREDICTION MODEL(PART OF RESULT)

\begin{tabular}{|c|c|c|c|c|}
\hline NO. & $\begin{array}{c}\text { maximum } \\
\text { absolute } \\
\text { error }\end{array}$ & $\begin{array}{c}\text { average } \\
\text { absolute } \\
\text { error }\end{array}$ & $\begin{array}{l}\text { maximum } \\
\text { relative } \\
\text { error }(\%)\end{array}$ & $\begin{array}{c}\text { average } \\
\text { relative } \\
\text { error }(\%)\end{array}$ \\
\hline 1 & 56.98 & 12.72 & 63.11 & 14.98 \\
\hline 2 & 29.81 & 9.32 & 31.57 & 9.96 \\
\hline 3 & 10.35 & 11.86 & 9.76 & 8.34 \\
\hline 4 & 39.18 & 13.97 & 48.29 & 16.21 \\
\hline 5 & 40.53 & 14.87 & 21.56 & 12.67 \\
\hline$\ldots \ldots$ & ....... & ....... & $\ldots \ldots$ & ....... \\
\hline
\end{tabular}

\section{B. Pretreating the Data of Knowledge Itemset D}

There were some unpredictable human factors in the recording process, which could cause false data that would influence on the association rules. So each record needed pretreatment including data cleaning and data transformation, furthermore, data cleaning means that the noisy data and irrelevant data with the association rules should be cleared, which directly affects the effectiveness of the final association rules; data transformation means that the data should be transformed into the storage schema being apt to data mining.

In this paper, specific characters were substitute for input parameters, which were shown in Table 1 and the knowledge itemset D was shown in Table 3.

TABLE III. THE KNOWLEDGE ITEMSET D

\begin{tabular}{|c|c|c|c|}
\hline NO. & The selected parameters & Average error & Maxium error \\
\hline 1 & $1,3,4,6,8,10,17,25$ & high & high \\
\hline 2 & $2,3,4,7,9,10,13,18$ & high & low \\
\hline 3 & $2,4,6,8,10,22,23$ & low & low \\
\hline 4 & $1,3,4,8,9,11,14,16$ & high & high \\
\hline 5 & $1,2,4,8,10,13,19,20$ & low & high \\
\hline$\ldots .$. & $\ldots \ldots$ & $\ldots \ldots$ & $\ldots \ldots$ \\
\hline
\end{tabular}

\section{The Data Mining Results}

For the first time, the support level and trust level were selected freely for data mining based on association rules using Apriori algorthm with the results in Table 4.

TABLE IV. THE DATA MINING RESULTS FOR THE FIRST TIME

\begin{tabular}{|c|c|c|c|c|c|c|}
\hline NO. & $\begin{array}{l}\text { support } \\
\text { level }\end{array}$ & $\begin{array}{l}\text { trust } \\
\text { level }\end{array}$ & \multicolumn{3}{|c|}{$\begin{array}{l}\text { sensitivity } \\
\text { parameter }\end{array}$} & $\begin{array}{c}\text { prediction } \\
\text { precision }\end{array}$ \\
\hline \multirow{3}{*}{1} & \multirow{3}{*}{0.1} & \multirow{3}{*}{0.9} & 5 & 7 & 18 & $\begin{array}{c}\text { the average error is } \\
\text { high }\end{array}$ \\
\hline & & & 7 & 12 & 18 & $\begin{array}{l}\text { the average error is } \\
\text { high }\end{array}$ \\
\hline & & & 1 & 8 & & $\begin{array}{l}\text { the maxium error is } \\
\text { low }\end{array}$ \\
\hline \multirow{4}{*}{2} & \multirow{4}{*}{0.2} & \multirow{4}{*}{0.9} & 4 & 5 & 18 & $\begin{array}{l}\text { the average error is } \\
\text { high }\end{array}$ \\
\hline & & & 5 & 7 & 18 & $\begin{array}{l}\text { the average error is } \\
\text { high }\end{array}$ \\
\hline & & & 4 & 18 & & $\begin{array}{l}\text { the average error is } \\
\text { high }\end{array}$ \\
\hline & & & 5 & 18 & & $\begin{array}{l}\text { the average error is } \\
\text { high }\end{array}$ \\
\hline
\end{tabular}

In Table 4, it is observed that parameter 5 and parameter 18 led to poor accuracy of the neural network prediction model of cervical spinal cord injury, therefore, we removed them for second data mining with the further operation results in Table 5 .

TABLE V. THE DATA MINING RESULTS FOR THE SECOND TIME

\begin{tabular}{|c|c|c|c|c|c|c|}
\hline NO. & $\begin{array}{c}\text { support } \\
\text { level }\end{array}$ & $\begin{array}{l}\text { trust } \\
\text { level }\end{array}$ & \multicolumn{3}{|c|}{$\begin{array}{l}\text { sensitivity } \\
\text { parameter }\end{array}$} & prediction precision \\
\hline \multirow[t]{3}{*}{1} & \multirow[t]{3}{*}{0.2} & \multirow[t]{3}{*}{0.9} & 3 & 4 & 6 & $\begin{array}{c}\text { the maxium error is } \\
\text { low }\end{array}$ \\
\hline & & & 6 & 8 & 13 & $\begin{array}{l}\text { the average error is } \\
\text { low }\end{array}$ \\
\hline & & & 3 & 6 & & $\begin{array}{l}\text { the maxium error is } \\
\text { low }\end{array}$ \\
\hline \multirow[t]{4}{*}{2} & \multirow[t]{4}{*}{0.2} & \multirow[t]{4}{*}{0.8} & 3 & 4 & 6 & $\begin{array}{c}\text { the maxium error is } \\
\text { low }\end{array}$ \\
\hline & & & 4 & 6 & 9 & $\begin{array}{l}\text { the maxium error is } \\
\text { low }\end{array}$ \\
\hline & & & 9 & 10 & & $\begin{array}{l}\text { the average error is } \\
\text { low }\end{array}$ \\
\hline & & & 3 & 4 & 8 & $\begin{array}{l}\text { the maxium error is } \\
\text { low }\end{array}$ \\
\hline
\end{tabular}


In Table 5, it is observed that parameter 3, parameter 4 or parameter 6 led to satisfied accuracy of the neural network prediction model of cervical spinal cord injury, therefore, we focused on them for third data mining with the further operation results in Table 6.

TABLE VI. THE DATA MINING RESULTS FOR THE THIRD TIME

\begin{tabular}{|c|c|c|c|c|c|c|c|c|c|}
\hline NO. & $\begin{array}{c}\text { support } \\
\text { level }\end{array}$ & $\begin{array}{l}\text { trust } \\
\text { level }\end{array}$ & \multicolumn{6}{|c|}{ sensitivity parameter } & $\begin{array}{l}\text { prediction } \\
\text { precision }\end{array}$ \\
\hline \multirow{3}{*}{1} & \multirow{3}{*}{0.2} & \multirow{3}{*}{0.9} & 3 & 4 & 6 & 8 & 10 & 13 & $\begin{array}{l}\text { the maxium } \\
\text { error is low }\end{array}$ \\
\hline & & & 1 & 2 & 3 & 6 & 8 & 9 & $\begin{array}{l}\text { the maxium } \\
\text { error is low }\end{array}$ \\
\hline & & & 11 & 17 & & & & & $\begin{array}{l}\text { the maxium } \\
\text { error is low }\end{array}$ \\
\hline \multirow{3}{*}{2} & \multirow{3}{*}{0.2} & \multirow{3}{*}{0.8} & 3 & 4 & 6 & 8 & 10 & 13 & $\begin{array}{l}\text { the maxium } \\
\text { error is low }\end{array}$ \\
\hline & & & 11 & 12 & 17 & & & & $\begin{array}{l}\text { the average } \\
\text { error is } \\
\text { high }\end{array}$ \\
\hline & & & 11 & 17 & 23 & & & & $\begin{array}{l}\text { the average } \\
\text { error is } \\
\text { high }\end{array}$ \\
\hline
\end{tabular}

In Table 6, it is observed that parameter 11 and parameter 17 could improve prediction accuracy while parameter 11, parameter 12 and parameter 17 were selected at the same time could reduce the prediction accuracy, which indicated that the parameters could affect the prediction precision of prediction model, as well as had inter-effect on each other.

\section{CONCLUSION}

In conclusion, 7 parameters were selected for the neural network prediction model of cervical spinal cord injury: age, injury cause, injury degree, elapsed time to hospital, blood pressure, heart rate and injury segment. Further more, the results showed that the ANN prediction accuracy ,system stability and antijamming were improved and the training time was also reduced for using data mining based on association rules, which proved that association rules could select input parameters of the neural network prediction model of cervical spinal cord injury and reduces its dimensionality effectively.

\section{ACKNOWLEDGEMENT}

In this paper, the research was sponsored by the Research Fund for the Doctoral Program of Bohai University (Project No. 0515bs026).

\section{REFERENCES}

[1] Murat Karabatak , M. Cevdet Ince , "An expert system for detection of breast cancer based on association rules and neural network", Expert Systems With Applications, pp. 3465-3469, 2008(02).

[2] Aicha Boutorh , Ahmed Guessoum, "Complex diseases SNP selection and classification by hybrid Association Rule Mining and Artificial Neural Network-based Evolutionary Algorithms”, Engineering Applications of Artificial Intelligence, pp. 58-70, 2016(10).

[3] Cheng Yeh , Che-hui Lien m, Tao-Ming Ting, Yi-Yun Wang, Chin-Ming Tum , "Cosmetics purchasing behavior - An analysis using association reasoning neural networks”, Expert Systems With Applications, pp. 7219-7226, 2010(10).

[4] B. Dhanalaxmi , G. Apparao Naidu ,K. Anuradha , “Adaptive PSO Based Association Rule Mining Technique for Software Defect Classification Using ANN”, pp. 432-442, 2015(02).

[5] Amit Bhagat , Sanjay Sharma , Dr. K.R.Pardasani , "Feed Forward Neural Network Algorithm for Frequent Patterns Mining”, pp.201-202,
2010(08).

[6] John F. Kros , Mike Lin , Marvin L. Brown , "Effects of the neural network s-Sigmoid function on KDD in the presence of imprecise data”, Computers and Operations Research, pp. 3136-3149, 2015(11).

[7] Tongyan Li , Xingming Li . "Novel alarm correlation analysis system based on association rules mining in telecommunication networks", Information Sciences, pp.2960-2978, 2010(16). 